$\begin{array}{ll}\text { Volume } & : 7 \\ \text { Nomor } & : 3 \\ \text { Bulan } & : \text { Agustus } \\ \text { Tahun } & : 2021\end{array}$

\section{Manusia dengan Lingkungan Alam dalam Novel Aroma Karsa Karya Dee Lestari} (Kajian Ekokritik Sastra)

\author{
Sartina \\ Universitas Negeri Gorontalo \\ Pos-el: sartinapadju1@gmail.com
}

Salam

Universitas Negeri Gorontalo

Pos-el: salamtolaki@ung.ac.id

Zilfa Achmad Bagtayan

Universitas Negeri Gorontalo

Pos-el: zilfa@ung.ac.id

DOI: $10.32884 /$ ideas.v7i3.393

\begin{abstract}
Abstrak
Penelitian ini dilakukan untuk mengkaji interaksi para tokoh yang membentuk jalinan hubungan beserta perannya dalam lingkungan alam dalam novel Aroma Karsa Karya Dee Lestari. Tujuan penelitian ini yaitu, 1) mendeskripsikan interaksi manusia dengan lingkungan alam, dan 2) mendeskripsikan peran manusia terhadap lingkungan alam dalam novel Aroma Karsa Karya Dee Lestari menggunakan teori ekokritik sastra dengan memandang karya sastram, manusia, dan lingkungannya adalah aspek hidup yang tidak terpisahkan. Metode yang digunakan dalam penelitian ini adalah metode deskriptif kualitatif. Teknik pengumpulan data dalam penelitian ini menggunakan teknik baca, cata, dan teknik riset kepustakaan. Sedangkan teknik analisis data dalam penelitian ini mengindetifikasi bagian-bagian teks kutipan novel berdasarkan indikasi hubungan manusia dengan lingkungan alam, mengklasifikasikan, menganalisis, mendeskripsikan, serta menyimpulkan hasil analisis data. Hasil penelitian menunjukkan gambaran interaksi mengenai beberapa tokoh yang memiliki hubungan khusus dengan alam melalui indra penciumannya dan perjalanan beberapa tokoh yang dimaksudkan melakukan ekpedisi perlindungan tanaman Puspa Karsa dalam novel Aroma Karsa Karya Dee lestari dengan pendeskripsian bahwa manusia dapat memberikan peran berupa hal positif dan negatif pada lingkungan alam.
\end{abstract}

Kata Kunci:

manusia, ekokritik sastra, novel

\begin{abstract}
This research was conducted to examine the interaction of the relationshop-forming figures and their roles in the natural environment in the novel Aroma Karsa by Dee Lestari. The objectives of this study were 1) to describe human interactio with the natural environment, and 2) to describe the role of humans in the natural environment in the novel using literary ecocritical theory by reviewing literature, humans, and their environment as inseparable aspects of life. This study used a qualitative descriptive method, where the data collection techniques used technique of reading, takin notes, and literature study. Meanwhile, the data analysis technique in this study identified parts of the text of the novel excerpts based, on the indication of the human relationship with the natural environment, calculates, analyzes, describe, and concludes the results of the data analysis. The results showed a picture of the ineraction of several figures who had a special relationship with nature through their sense of smell and the journey of several figures who were intended to carry out an expedition to proted the Puspa Karsa plant in the novel Aroma Karsa by Dee Lestari with the description that human can provide positive and negative roles in the natural environment.
\end{abstract}

Keywords:

human, literary, ecocritic, novel 


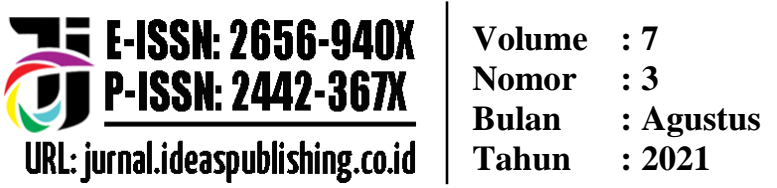

\section{Pendahuluan}

Karya sastra merupakan suatu ungkapan pemikiran, gagasan ataupun pengalaman yang kemudian diwujudkan sebagai sebuah kreativitas. Sumardjo \& Saini (1997:3-4) menyatakan bahwa sastra adalah ungkapan pribadi manusia berupa pengalaman pemikiran, perasaan, ide, semangat, keyakinan dalam suatu bentuk gambaran konkret yang membangkitan pesona dengan alat bahasa. Berdasrkan hal tersebut, tampak bahwa karya sastra mempunyai unsur-unsur berbentuk pemikiran, ilham, serta gagasan. Bagaikan wujud pemikiran atas suatu gagasan, karya sastra sanggup sebagai media untuk pengarang untuk menyampaikan pesan serta berbagai hal yang turut serta dirasakan oleh pengarang sehingga karya sastra merupakan refleksi dari lingkungan kehidupan yang secara tidak langsung akan mempengaruhi karya sastra.

Karya sastra sebagai refleksi dari lingkungan kehidupan yakni salah satu tempat untuk menuangkan suarasuara yang terjadi di alam raya. Alam harus diperlakukan sebaik mungkin karena alam adalah salah satu bagian penting dalam kehidupan manusia.Manusia membutuhkan alam untuk pertumbuhan dan perkembangannya, dan begitu pula sebaliknya.Alam membutuhkan manusia untuk merawat dan menjaganya. Menurut Sumardo (2007:9) Adanya keterkaitan atau hubungan yang erat antara manusia dan lingkungan yang akhirnya turut melahirkan pemikiran atau karya sastra bertemakan lingkungan alam.

Dalam kaitannya dengan kajian sastra, novel sebagai salah satu karya sastra, menawarkan dunia berisi model kehidupan yang diidealkan dan bersifat imajinatif, namun direalisasi dan dianalogikan dengan dunia nyata oleh pengarang (Nurgiyantoro dalam Yanti, 2015: 3) pada kenyataannya, pengalaman yang turut dirasakan oleh pengarang yang merupakan hasil interaksi manusia yang membentuk wujud suatu kreativitas karya sastra yang bertemakan lingkungan. Pengarang berusaha menempatkan alam serta lingkungan hidup sebagai sumber kreasi imajinatif pengarang. Sadar atu tidak karya sastra selalu berada ditengah-tengah lingkungan. Manusia adalah objek garap sastra. Lingkungan adalah pijakan sastra. Ekokritik sastra berupaya mencermati jejak ekologis dalam sastra. Kuswadi (Endraswara, 2016:80) merumuskan ihwal keterkaitan ekologi dalam satra memang selalu ada. Keterkaitan secara resiprokal memang tidak terelakkan oleh karena antara alam, manusia, dan lingkungan senantiasa bergema.

Novel yang termasuk dalam karya sastra yang berwawasan ekologis dapat ditemui dalam novel Aroma Karsa karya Dee Lestari. Novel ini menggambarkan interaksi para tokoh yang membentuk jalinan hubungan beserta perannya dalam lingkungan alam. Novel ini juga mengisahkan perjalanan beberapa tokoh yang dimaksudkan melakukan ekpedisi pencarian tanaman Puspa Karsa. Tanaman tersebut dijelaskan hanya bisa diidentifikasi melalui aroma, melalui orang pilihan yang telah terikat secara batin dengan tanaman tersebut. Ekspedisi tersebut dipimpin oleh cucu Janirah yakni Raras Prayagung beserta Tanaya Suma, Jati, Lambang, Kapten Jindra, dan beberapa orang yang termasuk dalam rombongan lainnya. Ekpedisi itu memiliki tujuan untuk melindungi tanaman Puspa Karsa agar tidak jatuh ke tangan orang yang salah. Diceritakan juga mengenai beberapa tokoh yang memiliki hubungan khusus dengan alam yang membentuk suatu interaksi melalui penciumannya.

Hal yang begitu menarik dari Novel Aroma Karsa Karya Dee Lestari, yakni keadaan lingkungan hidup yang meliputi sesuatu di alam semesta, baik tempat tinggal, hutan, dan tumbuhan di deskripsikan secara jelas dan mendalam. dan peranan para tokoh yang berusaha melindungi tanaman Puspa Karsa serta permasalahan lingkungan bukan manusia hadir tidak hanya sebagai sebuah bingkai tetapi sebagai kehadiran yang menunjukkan interaksi manusia yang membentuk jalinan hubungan beserta perannya dalam lingkungan alam Hal ini bisa dipahami melalui perspektif ekokritik sastra.

Menurut Endraswara (2016:33) perbincangan manusia dalam karya sastra ada dua bentuk, yaitu: (1) perbincangan yang sengaja menggarap lingkungan dan (2) perbincangan yang sekadar menjadikan lingkungan sebagai suplemen. Baik disengaja maupun sekadar suplemen. Endraswara (2016: 81) pendekatan manusia sebagai individu dengan lingkungan hidupnya dapat diperjelas lagi maknanya atas dua elemen yakni: (1) fenomena fisis atau fakta yang dilihat, didengar, dan disentuh oleh invidu yang dimaksudkan sebagai peran penggerak yang berusaha menjaga, melestarikan, dan mendamaikan lingkungan terkait dengan keadaan bumi yang goyah akibat ulah manusia serta mengungkapkan peran manusia terhadap lingkungan juga sebaliknya dalam peta sastra. Lingkungan ditangan manusia dapat menguntungkan karena manusia dikaruniai kecerdasan ekologis. Dalam buku berjudul Aspect of the Novel, Forster (1998:10)meletakkan manusia pada posisi penting dalam sastra. Menjadi unsur pembangun novel, yang tidak mungkin terpisah dari lingkungannya. Hal senada juga disampaikan Stanton (2012:112-114) aspek manusia tergolong hal utama. Manusia yang mampu membuat 


$\begin{array}{ll}\text { Volume } & : \mathbf{7} \\ \text { Nomor } & : \mathbf{3} \\ \text { Bulan } & : \text { Agustus } \\ \text { Tahun } & : \mathbf{2 0 2 1}\end{array}$

E-ISSH: 2656-940X 강 P-ISSH: 2442-367K URL: jurnal.ideaspublishing.co.id

merah dan hijau lingkungan. (2) makna, tidak terlihat dari fenomena tersebut, kekuatan yang dan hukum yang melingkupi baik yang bersifat ilmiah, moral, maupun spritual yang berkaitan dengan pencarian hal ihwal penting tentang identitas pribadi manusia manusia sebagai pengembara yang selalu diidentikkan dengan lingkungan fisik.

Kenyataan tersebut memperlihatkan kompleksitas pengalaman manusia yang merupakan hasil interaksi manusia sebagai individu maupun makhluk sosial, dengan berbagai ekologi yang mengitarinya yang kompleks pula untuk membuat koneksi senada dengan pandangan Buell (dalam Endraswara 2016:26) yang dimaksudkan menekankan kemampuan kita dalam hal berkenalan secara intim dengan alam. Mengenal alam dalam sastra adalah kecenderungan kajan yang mengasumsikan bahwa seluruh alam sering hadir dalam sastra dalam bentuk yang berbeda.

Teori ekokritik sastra mengemukakan tentang hubungan manusia dengan dunia alam, bukan hanya mengekspos sikap konvesional, tetapi juga sebagai jembatan konseptualisasi manusia dengan kehidupannya, baik hubungan manusia dengan alam, manusia dengan tumbuh-tumbuhan, maupun manusia dengan hewan. Sejalan dengan pendapat Shoba (2018: 85) ekokritik adalah ilmu tentang budaya (seni, sastra, teori ilmiah dan lain-lain) dalam hubungannya dengan manusia dan alam. Ekokritik tidak hanya sebagai alat untuk mengkritik bagaimana seharusnya lingkungan direpresentasikan dalam karya tetapi pemahaman tentang kebiasaan hidup manusia yang ada di dalamnya.

Peran manusia dalam penelitian ini dimaksudkan pada berbagai tindakan para tokoh yang memperlihatkan aksi penyelematan dan perlindungan terhadap alam melalui perbincangan yang sengaja menggarap lingkungan yang dipertegas oleh Endraswara (2016: 81) pendekatan manusia sebagai individu dengan lingkungan hidupnya sebagai fenomena fisis atau fakta yang dilihat, didengar, dan disentuh oleh invidu yang dimaksudkan sebagai peran penggerak yang berusaha menjaga, melestarikan, dan mendamaikan lingkungan terkait dengan keadaan bumi yang goyah akibat ulah manusia serta mengungkapkan peran manusia terhadap lingkungan juga sebaliknya dalam peta sastra.

Pandangan ekokritik berusaha menghadirkan diskursus dan kritik terhadap manusia dalam relasinya dengan lingkungannya. Pada intinya, kajian ekokritik memaparkan inrelasi antara manusa dan bukan manusia dalam segala aspek kehidupan yang tidak dapat dipisahkan dengan lingkungan alam. Dengan konsep ekokritik sastra inilah yang merupakan studi tentang sastra dan lingkungan yang menganalisis karya sastra yang menggambarkan pola-pola hubungan yang terjalin serta kepedulian terhadap lingkungan. peranan tokoh yang berusaha melindungi tanaman Puspa Karsa.

Novel Aroma Karsa Karya Dee Lestari memuat unsur-unsur ekologi yang signifikan, karena pengarang menampilkan berbagai tokoh yang membentuk interaksi dan perannya masing masing terhadap lingkungan alamnya sehingga cocok dan menarik untuk diteliti menggunakan pendekatan ekokritik sastra yang meliputi interaksi tokoh dengan lingkungan dan peran tokoh terhadap lingkungan alam. Oleh karena itu, dalam penelitian ini peneliti memformulasikan judul "Manusia dengan Lingkungan Alam dalam Novel Aroma Karsa Karya Dee Lestari Kajian Ekokritik Sastra".

\section{Metode}

Pendekatan penelitian yang digunakan dalam penelitian ini adalah pendekatan penelitian kualitatif. Menurut Bogdan dan Taylor (dalam Margono 2007: 36) bahwa penelitian kualitatif adalah prosedur peneltian yang menghasilkan data deskriptif berupa kata-kata atau kalimat dari orang-orang dan perilaku yang dapat diamati. penelitian ini menggambarkan dan melakukan eksplorasi secara mendetail mengenai permasalahan yang diteliti.

Jenis penelitian yang digunakan adalah jenis penelitian deskriptif. Djojosuroto (2003:3) penelitian deskriptif merupakan penelitian berusaha menggambarkan peristiwa apa adanya, fenomena, atau realitas sosial yang aktual dan terjadi saat ini, kemudian dipahami dan dianalisis secara mendalam untuk memecahkan atau menjawab permasalahan yang sedang dihadapai pada situasi sekarang atau masalah yang aktual dengan jalan mengumpulkan, menyusun, mengklasifikasikan, menganalisis, dan interpretasi. Selaras dengan pendapat tersebut pendekatan penelitian ini digunakan untuk mendeskripsikan interksi beserta beserta peran manusia dengan lingkungan alam dalam novel Aroma Karsa karya Dee Lestari.

Data penelitian yang digunakan dalam penelitian ini adalah teks kutipan atau pernyataan yang merujuk pada pernyataan yang mengandung unsur manusia (tokoh cerita) dan interaksinya dengan lingkungan alam

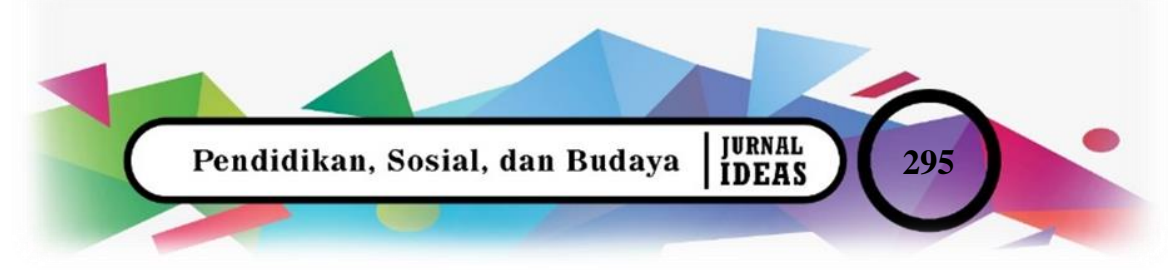




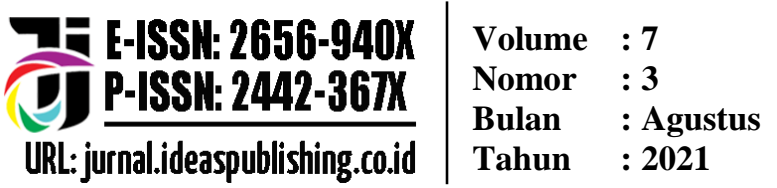

beserta peran manusia (tokoh cerita) terhadap lingkungan alam dalam novel Aroma Karsa Karya Dee Lestari sedangkan Sumber data yang digunakan dalam penelitian ini adalah novel Aroma Karsa Karya Dee Lestari, penerbit Bentang Pustaka tahun 2018 dengan jumlah halaman 702. Lalu, buku-buku teori yang berkaitan dengan masalah dalam penelitian ini.

Teknik pengumpulan data dalam penelitian ini menggunakan teknik baca, teknik catat, dan teknik riset kepustakaan. Teknik riset kepustakaan yakni mencari dan menemukan data dari berbagai buku atau pustaka sebagai referensi yang mendukung subjek dan fokus penelitian dengan mengaplikasikan data berdasarkan teori yang sesuai.

Teknik analisis data yang digunakan setelah data terkumpul, yaitu Meninjau kembali hasil temuan data yang telah dikumpulkan kemudian mengindetifikasi data yang telah ditandai berkaitan dengan permasalahan manusia dan interaksinya dengan lingkungan alam beserta peran manusia terhadap lingkungan alam pada novel Aroma Karsa Karya Dee Lestari baik berupa kata, frasa, atau satu kalimat dengan mengkategorisasi, yakni kegiatan yang dilakukan dengan cara mengelompokan data yang sesuai dengan ciri tertentu yang sesuai dengan ciri masalah tentang interaksi manusia dengan lingkungan beserta peran manusia terhadap lingkungan alam dalam novel Aroma Karsa Karya Dee Lestari, menganalisis data yang menggambarkan interaksi manusia dengan lingkungan beserta peran manusia terhadap lingkungan alam dalam novel Aroma Karsa Karya Dee Lestari, mendeskripsikan teks yang berupa gambaran atau menjelaskan interaksi manusia dengan lingkungan beserta peran manusia terhadap lingkungan alam dalam novel Aroma Karsa Karya Dee Lestari, menginterpretasi teks berupa interaksi manusia dengan lingkungan alam beserta peran manusia terhadap lingkungan alam pada novel Aroma Karsa Karya Dee Lestari kemudian menyimpulkan hasil data yang berkaitan dengan interaksi manusia dengan lingkungan beserta peran manusia terhadap lingkungan alam dalam novel Aroma Karsa Karya Dee Lestari

\section{Hasil dan Pembahasan \\ Hasil}

Hasil penelitian ini adalah mengidentifikasi interaksi manusia dengan lingkungan alam serta peran manusia terhadap lingkungan alam dalam novel Aroma Karsa Karya Dee Lestari dengan menggunakan kajian Ekokritik Sastra. Deskripsi hasil penelitian rersebut disesuaikan dengan tujuan penelitian, yaitu mendeskripsikan interaksi manusia dengan lingkungan alam serta peran manusia terhadap lingkungan dalam novel Aroma Karsa Karya Dee Lestari.

\section{Interaksi Manusia (Tokoh Cerita) dengan Lingkungan Alam dalam Novel Aroma Karsa Karya Dee Lestari}

Hubungan atau interaksi manusia dengan kehidupannya meliputi hubungan atau interaksi manusia dengan alam, hubungan manusia dengan tumbuh-tumbuhan, atau hubungan manusia dengan hewan. Menurut Shoba (2018: 85) ekokritik adalah ilmu tentang budaya (seni, sastra, teori ilmiah dan lain-lain) dalam hubungannya dengan manusia dan alam. Kenyataan tersebut memperlihatkan kompleksitas pengalaman manusia yang merupakan hasil interaksi manusia sebagai individu maupun makhluk sosial, dengan berbagai ekologi yang mengitarinya yang kompleks pula untuk membuat koneksi senada dengan pandangan Buell (dalam Endraswara 2016:26) yang dimaksudkan menekankan kemampuan kita dalam hal berkenalan secara intim dengan alam.

Mengenal alam dalam sastra adalah kecenderungan kajan yang mengasumsikan bahwa seluruh alam sering hadir dalam sastra dalam bentuk yang berbeda yakni melihat para tokoh dalam novel yang mempunyai hubungan khusus dengan alam yang membentuk sebuah interaksi permasalahan lingkungan yang ada dalam novel Aroma Karsa. Permasalahan lingkungan bukan manusia hadir tidak hanya sebagai sebuah bingkai tetapi sebagai kehadiran yang menunjukkan interaksi manusia yang membentuk jalinan hubungan beserta perannya dalam lingkungan alam dengan menerapkan kajian ekokritik sastra yang terdapat dalam novel.

Interaksi yang ditunjukkan oleh beberapa tokoh dalam novel tersebut seperti sosok Janirah yang memiliki hubungan yang mendalam antara dirinya dengan tanaman hal itu ditunjukkan mulai dari aroma badan Janirah hingga ke hiasan-hiasan seisi rumah Janirah yang dipenuhi dengan cendana, kangga dan berbaga i tanaman lainnya yang dtunjukkan melalui kutipan berikut.

"Bola-bola kayu cendana yang tahunan menyelip di sana sini menjenuhkan barang-barang di kamar itu dengan wanginya yang lestari. Kesegaran melati dan kelanggengan cendana menemani Eyang Putri sepanjang hidupnya di rumah itu” (Lestari, 2018:2). 


$\begin{array}{ll}\text { Volume } & : 7 \\ \text { Nomor } & : 3 \\ \text { Bulan } & : \text { Agustus } \\ \text { Tahun } & : 2021\end{array}$

Tahun : 2021
E-ISSH: 2656-940X 간 P-ISSH: 2442-367K URL: jurnal.jdeaspublishing.co.id

Tokoh Raras Prayagung yang merupakan cucu dari Janirah juga memiliki hubungan interaksi antara dirinya dengan lingkungan alam. Hal itu juga tidak terlepas dari sosok Eyangnya yang memperkenalkan Raras dengan berbagai tanaman untuk menciptakan dunia aroma. Kemudia tokoh Suma dan Jati yang memiliki kisah unik proses perkenalannya dengan segala hal yang menyangkut lingkungan alam disekitarnya. Mereka berusaha membaui dan mengenal sebutann-sebutan berbagai tumbuhan melalui indra penciuman yang dimiliki oleh keduanya hingga Jati dapat memprediksi kapan datangnya badai melalui proses tanda yang diterimanya dari berbagai tanaman dan aroma tanah yang menunjukkan reaksi.

"Menjelang hujan turun, segala wewangian akan tercium lebih tajam baginya, tadi, wangi asiri dari sayatan rumput begitu pekat sampai-sampai hidungnya gatal. Yang bakal hadir bukan hujan biasa, demikian Jati menyimpulkan. Hidungnya mengendus kedatangan badai. Ingin Jati menyampaikan kepada Nurdin, tapi entah harus mulai darimana” (Lestari, 2018:31).

Tokoh Jati dapat mengetahui datangnya badai melalui insting hidungnya yang kemudian dibenarkan oleh aroma khas asiri rumput yang menguar begitu pekat. Fenomena tersebut merupakan reaksi alamiah tumbuhan mengalami fase defensif dengan meningkatkan kadar kalsium dan beberaa zat lainnya sebagai upaya melindungi diri dari bakteri-bakteri berbahaya ketika hujan datang. Dari gambaran di atas tampak diketahui bahwa melalui fenomena tersebutlah yang memberikan rangsangan pada tokoh Jati untuk mengetahui hal-hal yang terjadi di lingkungan sekitarnya. berarti Jati telah mempelajari dan kemudian memiliki pengetahuan yang luas berkat interaksi yang dibangunnya bersama aroma yang ditemui di lingkungan alam. Jati dari hari ke hari mengamati berbagai macam aroma yang ditemuinya dari manusia, hewan, bunga, dan berbagai tanaman lainnya

Jati memiliki hasrat dan dorongan untuk mengetahui lebih dalam fenomena yang terjadi di lingkungan sekitarnya. Jati lebih tertarik mengamati hal yang tidak umum bagi manusia lainnya. Apa yang dia amati kemudian di catat dalam buku perjalanan interaksinya yang sangat dia rahasiakan, termasuk beberapa interaksi yang terjadi antara dia, Suma, dan Raras dengan tanaman Puspa Karsa. Terdapat juga beberapa tokoh yang menunjukkan interaksi serupa seperti arkeolog Lambang dan Sudajtmiko yang diceritakan sebagai sosok yang sangat mengenal berbagai macam tanaman nusantara dan membentuk suatu hubungan intim dengan berbagai anggrek yang dikoleksinya.

"Sejak Bapak meninggal, anggreknya ikut mati satu-satu. Padahal sudah saya urus seperti caranya Bapak mengurus. Tapi, mereka seperti ngadat” (Lestari, 2018:308).

Begitupun tokoh Mbah Jo yang juga ikut terlibat dalam ekspedisi pencarian tanaman Puspa Karsa. Mbah Jo adalah sosok juru kunci Gunung Lawu yang memiliki peran sangat penting karena ia dipercaya oleh penduduk sekitar dan para pendaki bahwa Mbah Jo dan Gunung Lawu memiliki hubungan dengan Gunung Lawu. Semua yang akan naik ke Gunung Lawu harus memiliki izin dari Mbah Jo.

"Dari ujung ruangan, Jati mencium beberapa aroma menarik ketika sosok Mbah Jo memasuki ruang tamu. Ada aroma asiri yang belum ia kenali sebelumnya, halus berdiri di balik bau tembakau dan mesin mobil. Seperti aroma eukaliptus bercampur papermin. Dari karakternya, Jati menduga asiri itu berasal dari kayu” (Lestari, 2018: 491).

Mbah Jo merupakan juru kunci di gunung Lawu. Ketika bertemu dengan Jati, Mbah Jo memiliki aroma menarik yang bisa dibaui oleh Jati seperti asiri yang Jati belum kenali, berlanut kemudian Jati mulai menganalisa dari rokok kretek yang dihisap oleh Mbah Jo sehingga ia bisa mnyimpulkan darimana aroma itu berasal. Pertemuan itu mendapatkan tentangan dari Mbah Jo sebaga juru kunci, dirinya mengingatkan Raras bahwa alam tidk memberikan izin bagi mereka naik ke Lawu. banyaknya kabut yang dipercaya masayarakat sekitar Gunung Lawu menjadi penegas perkataan Mbah Jo.

"Mereka yang berada di dekat Gunung Lawu tak mungkin melupakan bagaimana kabut yang disebut ampuk-ampuk mengelilingi bagian tengah gunug seperti cincin kelabu selama berhari-hari. Pendakian dari semua jalur dihentikan sementara waktu. Penduduk memanjatkan doa-doa khusus agar kondisi gunung kembali normal. Bertepatan dengan itu, juru kunci Gunung Lawu, Mbah To, terbaring sekarat karena penyakit misterius yang datang serta-merta” (Lestari, 2018: 612).

Mbah To adalah Ayah dari Mbah Jo. Sebelumnya, Mbah Jo merupakan juru kunci Gunung Lawu hingga akhirnya meninggal dan mewarisi pekerjaannya kepada anaknya. Sebagai Juru kunci, tentunya hal tersebut sangat sakral bagi penduduk sekitar bahwa Mbah Jo benar-benar manusia pilihan yang dipilih langsung oleh Gunung Lawu untuk menjadi penyambung interaksi antara penduduk sekitar dan pendaki Gunung Lawu. Ketika

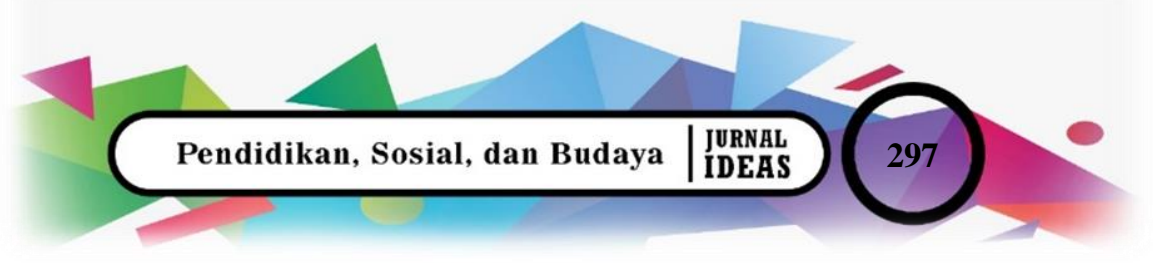




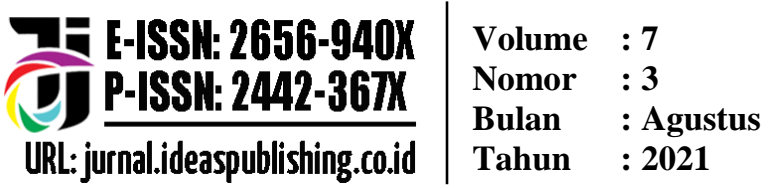

ekspedisi pertama Puspa Karsa mengalami kendala yang serius, Gunung Lawu seperti mengirimkam tanda kepada penduduk sekitar bahwa sesuatu yang tidak beres tengah terjadi. Fenomena Gunung Lawu benar saja seperti memberikan informasi kepada penduduk sekitar untuk langsung memanjatkan doa-doa. Sakitnya Mbah Jo sebagai juru kunci Gunung lawu juga kemudian menjadi penegas apa yang sebenarnya tengah terjadi.

"Di bawah sana, di Desa Ngargoyoso, penduduk berkasak-kusuk tentang ampuk ampuk yang bercokol lebih dari sepekan dan akhirnya menghilang begitu saja pada suatu pagi. Bertepatan dengan itu, juru kunci Gunung Lawu, Mbah To, mengembuskan napas terakhir” (Lestari, 2018:616).

Kabut Gunung Lawu yang terus menerus semakin mengelilingi gunung tersebut membuat warga sekitar menjadi panik hal ini tentunya hal ini sejalan dengan pendapat Endraswara (2016:23) Dialektika tempat (lingkungan) dan manusia sering hadir dalam permainan estetika sastra. Atas dasar lingkungan alam sebagai tempat berkiprah sastra, seringkali fenomena itu mencerminkan perkembangan sosial dan wacana budaya. Oleh karena itu, ekokritik sastra adalah sebagai perspektif kajian sastra yang dapat memberikan penerangan untuk mengungkapkan materi yang kompleks tentang lingkungan, keadaan sosial, dan interkoneksi ekologi biotik dengan teks sastra. Dalam kutipan novel tersebut dapat diketahui bagaimana lingkungan membangun koneksi dengan manusia.

Peran Manusia (Tokoh Cerita) terhadap Lingkungan Alam dalam Novel Aroma Karsa Karya Dee Lestari

Manusia sebagai makhluk biologis juga memainkan perananannya dalam menjaga alam atau lingkungan hidup, menciptakan keseimbangan dengan alam, tumbuh-tumbuhan, dan manusia dengan hewan. Berbagai permasalahan lingkungan yang seringkali dianggap sebelah mata oleh sebagain besar manusia justru menarik perhatian beberapa orang yang tentunya masih memiliki kepedulian terhadap menjaga dan melestarikan lingkungan.

Novel Aroma Karsa karya Dee Lestari mengisahkan tentang perjalanan beberapa tokoh yang dimaksudkan melakukan ekpedisi pencarian untuk perlindungan tanaman Puspa Karsa. Tanaman tersebut dijelaskan hanya bisa diidentifikasi melalui aroma, melalui orang pilihan yang telah terikat secara batin dengan tanaman tersebut. Tanaman Puspa Karsa perlu disembunyikan keberadaannya. Janirah sebagai sosok yang menunjukkan kekhawatirannya akan penemuan Puspa Karsa oleh orang yang salah. Bukan hanya Janirah, Raras Prayagung pun turut menunjukkan perannya sebagai penerus Janirah dalam melakukan ekpedisi melindungi Puspa karsa

"Saking percayanya Mbakyu Janirah kalau Puspa Karsa itu ada, pesannya kepadaku cuma satu. Jangan publikasikan soal Mahesa Guning. Beliau khawatir orang-orang nggak jelas nanti malah berlomba-lomba cari Puspa Karsa macam berburu harta Karun” (Lestari, 2018: 19).

"Saya tidak bermaksud merahasiakannya terus-menerus. Demi kebaikan bersama, kita perlu kasih jeda waktu yang cukup untuk mengkaji temuan kita sebelum mngumumkannya ke publik. Bisa dibilang saat ini kita tidak tahu apa-apa tentang Puspa Karsa. Potensinya, kekuatanya, bahayanya. Apa jadinya kalau tanaman itu jatuh ke tangan pihak yang salah” (Lestari, 2018: 301).

Tokoh Janirah dan Raras Prayagung diceritakan sebagai sosok yang menunjukkan perannya dalam hal menanamkan pada orang lain akan pentingnya cinta terhadap bunga anggrek. Janirah juga terkenal sebagai kolektor anggrek yang disegani karena kegigihannya. Hal ini dibuktikan dengan cara Janirah mengirimi rekanrekannya bunga anggrek hingga mereka juga turut menyukai mengoleksi dan merawat bunga tersebut.

"Raras menghirup udara di kamarnya dalam-dalam. Sama seperti neneknya dahulu, ia menyebar bokorbokor kuningan berisi melati dan menjenuhkan barang-barangnya dengan aroma bola-bola cendana" (Lestari, 2018: 23).

"Yang paling mengesankan bagi Raras adalah kemampuan Janirah menulari orang-orang dengan kecintaanya pada anggrek. Neneknya sering dengan sengaja mengirim tanaman anggrek, dua-tiga kali, bahkan lebih dari sepuluh kali, sampai orang yang dikirimi lama-lama mulai ikut mengoleksi. Janirah melakukannya seperti sebuah misi” (Lestari, 2018: 18).

Ekspedisi pencarian Puspa Karsa dipmpin oleh cucu Janirah yakni Raras Prayagung beserta Tanaya Suma, Jati, Lambang, Kapten Jindra, dan beberapa orang yang termasuk dalam rombongan lainnya. Ekpedisi itu memiliki peranan dengan tujuan untuk melindungi tanaman Puspa Karsa agar tidak jatuh ke tangan orang yang salah.

Raras percaya bahwa ekspedisi kedua yang dilakukannya sudah dipersiapkan secara matang dan benarbenar. Ia benar-benar telah berusaha dengan keras dan membenarkan bahwa ekspedisi pertamanya dengan Prof. 


$\begin{array}{ll}\text { Volume } & : 7 \\ \text { Nomor } & : 3 \\ \text { Bulan } & : \text { Agustus } \\ \text { Tahun } & : 2021\end{array}$

Tahun : 2021
E-ISSH: 2656-940X 군 P-ISSH: 2442-367K URL: jurnal.ideaspublishing.co.id

Sudjatmiko masih minim petunjuk dan menyebabkan banyaknya kejadian yang seharusnya tidak terjadi pada ekpedisi tersebut.

"Saya mencari satu tanaman. Ada beberapa ahli yang saya kirim. Kamu akan mendampingi mereka. Dengan kondisi kaki begini, saya tidak mungkin ikut. Kalau tanaman yang saya cari itu berhasil ditemukan, saya butuh kamu untuk memastikan tidak ada pihak lain mengambil alih" (Lestari, 2018: 320).

Raras memegang peranan dalam hal memastikan penemuan Puspa Karsa benar jatuh ditangannya meski dirinya sendiri memiliki keterbatasan fisik yang menjadi kendalanya. Tapi itu tidak menyurutkan keinginannya agar tanaman tersebut tidak diambil oleh pihak lain yang masih diragukan tujuannya.

"Raras menghirup udara di kamarnya dalam-dalam. Sama seperti neneknya dahulu, ia menyebar bokorbokor kuningan berisi melati dan menjenuhkan barang-barangnya dengan aroma bola-bola cendana" (Lestari, 2018: 23).

Melalui Janirah Raras banyak belajar tentang berbagai hal tentang tanaman. Janirah menanamkan kecintaan tanaman kepada Raras, cucunya. Janirah memiliki peran untuk merawat dan melestarikan tanaman dengan berbagai caranya seperti membiasakan diri dengan wewangian tanaman di sekitar rumahnya. Raras dan Janirah menerapkan suasana tempat tinggl yang memiliki nuansa alam yang begitu kental.

Pesan-pesan dikemas dengan cara yang unik. Kehidupan sosok seorang Jati Wesi juga begitu menginspirasi. Bagaimana ia tumbuh besar di TPA Bantar Gebang, dan akrab dengan aroma busuk yang memuakkan. Proses kehidupan Jati otodidak mengasah kemampuannya untuk saling berkaitan dengan lingkungannya. Hal ini bermakna bahwa dari kehidupan yang paling terburuk pun seseorang akan mendapat pengalaman dan pembelajaran yang lebih baik. Karena Jati sudah ditempa langsung oleh lingkungan yang penuh tantangan.

Jati, sebagai orang yang paling utama diistimewakan Raras dalam pencarian Puspa Karsa berdasarkan proses kehidupan Jati yang mengasah kemampuannya secara langsung dalam mengenal dunia aroma tentunya menjad pertimbangan yang matang bagi Raras. Sebab, tanaman Puspa Karsa hanya bisa diidentifikasi melalui aroma.

"Kamu ikut. Kamu akan bantu menemukan Puspa Karsa dengan penciumanmu.

Tanaman itu belum pernah diidentifikasi, Jati. Ini akan jadi temuan baru” (Lestari, 2018:347).

Jati beserta anak buah Nurdin yang lain tentunya berpengaruh besar bagi lingkungan sekitar Bantar Gerbang. Mereka berusaha mencukupi kebutuhan hidup dengan berkerja sebagai pemulung sampah yang tentunya sangat membantu pengolahan sampah yang berguna berdasarkan semakin sulitnya penanganan sampah di lingkungan perkotaan.

"Sebagian menyaring sampah dari pasar basah dan mengolahnya menjadi pupuk. Jati salah seorang dari kelompok kedua" (Lestari, 2018: 44).

Menelisik dari bebrapa data yang ditemukan dalam novel Aroma Karsa karya Dee Lestari menunjukkan gambaran peran manusia terhadap lingkungan alam dari segi ekokritik adalah banyak menggambarkan bagaiman hubungan yang terjalin antara manusia dengan lingkungan hidupnya beserta peranan yang dipegang langung oleh manusia itu sendiri dalam menjaga dan merawat alam. digambarkan mengenai peranan lain yang dipegang oleh manusia.

"Bukannya tiap malam 1 Sura ribuan orang mendaki kemari? Nggak habis apa tempat ini di acak-acak? Bagaimana mau ada tanaman langka" (Lestari, 2018: 511).

"Sementara kita tahu hewan yang terancam akan balas menyerang, dan mereka punya kemampuan indrawi yang jauh lebih baik dari kita" (Lestari, 2018: 676).

Dalam novel tersebut menceritakan juga mengenai manusia kadang memanfatkan lingkungan alam dalam hal yang tidak sebagaimana mestinya banyaknya kerusakan yang terjadi membuat tanaman-tanaman yang tadinya memiliki manfaat banyak bagi kehidupan manusia menjadi sulit ditemukan akibat keserakahan dari manusia itu sendiri. Begitupun dengan hewan-hewan liar yang banyak dibunuh oleh manusia untuk diambil kulitnya dan bagian tubuh lainnya hanya untuk kepetingan pribadi manusia itu sendiri. Dalam meracik sebuah kisah pencarian melalui aroma novel tersebut merupakan fiksi yang begitu nyaris mendekati sebuah kenyataan kehidupan lingkungan.

"Di Lawu ada anggrek degleng. bisa jadi obat" (Lestari, 2018: 510). 
"Ada keahlian tertentu yang wajib dikuasai penduduk Dwarapala. Kaum lelaki wajib mampu berburu, bercocok tanam, bertukang, serta mengolah buah kapas menjadi benang. Kaum perempuan wajib mampu mengolah makanan, membuat tali, menenun kain, dan mewarnainya dengan lumpur yang diragikan. Perempuan-perempuan yang bertangan terampil lantas menghias kain-kain Dwarapala dengan cairan lilin tawon yang diberi aneka kelir dari bubuk kunyit, daun taru, biji kesumba, dan akar mengkudu” (Lestari, 2018: 610).

Berdasarkan kutipan di atas menjelaskan Mmanusia menempatkannya perannya dalam lingkungan alam untuk menggunakan bahan-bahan alam yang bisa digunakan bagi kebutuhan hidup juga pengobatan. Seperti membangun tempat tinggal dari bahan yang ada di alam, membuat makanan dan lainnya. Hal ini tergambar melalui penduduk Dwarapala yang menggunakan alam sebagai kebutuhan sehari-hari mereka.

\section{Pembahasan}

Hubungan manusia dengan lingkungannya bukan sekadar hubungan yang terjalin secara kebetulan, tetapi dalam segala aspek kehidupan yang tidak dapat dipisahkan dengan lingkungan alamlah yang menjadi jembatan konseptualisasi manusia dengan kehidupannya, baik hubungan manusia dengan alam, manusia dengan tumbuhtumbuhan, maupun manusia dengan hewan. novel Aroma Karsa karya Dee Lestari dilihat dari segi ekokritik sastra banyak menggambarkan bagaimana hubungan yang terjalin antara manusia dengan lingkungan hidupnya Interaksi manusia dengan lingkungan alam dalam novel Aroma Karsa Karya Dee Lestari yang memiliki hubungan khusus dengan alam, banyak digambarkan oleh tokoh Suma dan Jati yang memiliki kisah unik proses perkenalannya dengan segala hal yang menyangkut lingkungan alam disekitarnya.

Jati dan Suma berusaha membaui dan mengenal sebutan-sebutan berbagai tumbuhan melalui indra penciuman yang dimiliki oleh keduanya. dan beberapa gambaran interaksi yang terjadi antara Jati, Suma, dan Raras dengan tanaman Puspa Karsa. Terdapat juga beberapa tokoh yang menunjukkan interaksi serupa seperti arkeolog Lambang dan Sudajtmiko yang diceritakan sebagai sosok yang sangat mengenal berbagai macam tanaman nusantara dan membentuk suatu hubungan intim dengan berbagai anggrek yang dikoleksi dan ayam kate milik keduanya.

Suma dan Jati yang mempunyai hubungan khusus dengan alam yang membentuk sebuah interaksi melalui proses perkenalannya dengan dunia aroma dan beberapa permasalahan lingkungan yang ada dalam novel Aroma Karsa. Hal itu menunjukkan peranan para tokoh yang terlibat yang berusaha melindungi tanaman Puspa Karsa yang hanya bisa ditemukan melalui aromanya. Peran manusia terhadap alam dalam novel Aroma Karsa menunjukkan pola-pola hubungan yang terjalin serta kepedulian terhadap lingkungan. Peranan para tokoh yang berusaha melindungi tanaman Puspa Karsa. Janirah dan Raras Prayagung sebagai sosok yang menunjukkan kekhawatirannya akan penemuan Puspa Karsa oleh orang yang salah. Bukan hanya Janirah, Raras Prayagung pun turut menunjukkan perannya sebagai penerus Janirah dalam melakukan ekpedisi melindungi Puspa karsa. Tokoh Janirah dan Raras Prayagung juga menunjukkan perannya dalam hal menanamkan pada orang lain akan pentingnya cinta terhadap berbagai tanaman. Dalam novel tersebut menceritakan juga mengenai manusia kadang memanfatkan lingkungan tidak sebagaimana mestinya banyaknya kerusakan yang terjadi membuat Gunung Lawu dalam penceritaan novel tersebut banyak perburuan tanaman langka dan hewan liar.

Hasil pembacaan novel Aroma Karsa karya Dee Lestari yang berfokus pada teori ekokritik sastra pun dapat menjadi bahan acuan dalam pembelajaran sastra di SMA kelas XII, yakni pada KD 3.4 menganalisis isi dan kebahasaan novel yang bertemakan lingkungan alam meliputi aspek kebahasaandan latar sosial budaya baik secara lisan maupun tulis tentang sehingga penelitian ini juga diharapkan menumbuhkan rasa kasih sayang kita sebagai manusia terhadap lingkungan alam. Dan memberikan kesadaran kepada pembaca tentang pentingnya peran manusia terhadap alam dan lingkungan hidup sebagai salah satu tempat yang memiliki pernanan penting dalam kehidupan.

\section{Simpulan}

Berdasarkan hasil analisis yang dikemukakan dalam novel Aroma Karsa Karya Dee Lestari dengan menggunakan kajian ekokritik sastra, maka peneliti dapat memberikan kesimpulan bahwa interaksi manusia dengan lingkungan alam dalam novel Aroma Karsa Karya Dee Lestari yang memiliki hubungan khusus dengan alam, banyak digambarkan oleh tokoh Suma dan Jati yang memiliki kisah unik proses perkenalannya dengan segala hal yang menyangkut lingkungan alam disekitarnya. Mereka berusaha membaui dan mengenal sebutann- 


$\begin{array}{ll}\text { Volume } & : 7 \\ \text { Nomor } & : 3 \\ \text { Bulan } & : \text { Agustus } \\ \text { Tahun } & : 2021\end{array}$

Tahun : 2021
E-ISSI: 2656-940X 글 P-ISSI: 2442-367K URL: jurnal.ideaspublishing.co.id

sebutan berbagai tumbuhan melalui indra penciuman yang dimiliki oleh keduanya. dan beberapan gambaran interaksi yang terjadi antara Jati, Suma, dan Raras dengan tanaman Puspa Karsa. Terdapat juga beberapa tokoh yang menunjukkan interaksi serupa seperti arkeolog Lambang dan Sudajtmiko yang diceritakan sebagai sosok yang sangat mengenal berbagai macam tanaman nusantara dan membentuk suatu hubungan intim dengan berbagai anggrek yang dikoleksi dan ayam kate milik keduanya. Peran manusia terhadap alam dalam novel Aroma Karsa Karya Dee Lestari menunjukkan pola-pola hubungan yang terjalin serta kepedulian terhadap lingkungan. Peranan para tokoh yang berusaha melindungi tanaman Puspa Karsa. Janirah dan Raras Prayagung sebagai sosok yang menunjukkan kekhawatirannya akan penemuan Puspa Karsa oleh orang yang salah. Bukan hanya Janirah, Raras Prayagung pun turut menunjukkan perannya sebagai penerus Janirah dalam melakukan ekpedisi melindungi Puspa karsa. Tokoh Janirah dan Raras Prayagung juga menunjukkan perannya dalam hal menanamkan pada orang lain akan pentingnya cinta terhadap berbagai tanaman. Dalam novel tersebut juga diceritakan mengenai sifat manusia yang memanfatkan lingkungan tidak sebagaimana mestinya serta kerusakan yang terjadi sehingga membuat ekosistem di Gunung Lawu dan perburuan tanaman langka dan hewan liar.

\section{Daftar Rujukan}

Endraswara, Suwardi (ed). 2016. Sastra Ekologi: Teori dan Praktek Pengkajian. Yogyakarta: CAPS

Endraswara, Suwardi. 2016. Metode Penelitian Ekologi sastra: Konsep, Langkah dan Penerapannya. Yogyakarta: CAPS

Endraswara, Suwardi. 2020. Teori Sastra Terbaru Konsep dan Aplikasi. Jakarta Selatan: CV. Grafika Indah

Endraswara, Suwardi. 2016. Ekokritk Sastra. Yogyakarta: Morfalingua

Forster, EM. 1998. Aspect Of the Novel. Jakarta: Balai Pustaka.

Harsono, Siswo. 2008. Ekokritik: Kritik Sastra Berwawasan Lingkungan. Semarang: Kajian Sastra; Jurnal Kebahasaan dan Kesusastraan. Undip, Vol. 32 No. 1 Januari.

Juanda, J. (2016). Fenomena Eksploitasi Lingkungan dalam Cerpen Koran Minggu Indonesia. AKSIS: Jurnal Pendidikan Bahasa dan Sastra Indonesia, 2(2), 171.

Juanda, J. 2018. Eksplorasi Nilai Pendidikan Lingkungan Cerpen Republika: Kajian Ekokritik. Jurnal Sosial Humaniora: 11(2),67-81.

Juliasih. 2012. Manusia dan Lingkungan dalam Novel Life In The Iron Millis Karya Rebecca Hardings Davis. Jurnal Litera, Vol.11, No.1, April 2012. Hlm. 83-97

Margono, S. 2007. Metodologi Penelitian Pendidika. Jakarta: Rineka Cipta

Lestari, Dee. 2018. Aroma Karsa. Yogyakarta: PT Bentang Pustaka.

Nurgiyantoro, Burhan. 2013. Teori pengkajian Fiksi. Yogyakarta: Gajah Mada University Press

Nurgiyantoro, Burhan. 2000. Teori Pengkajian Fiksi. Yogyakarta: Gajah Mada University Press Gramedia.

Ratna, Nyoman Kutha. 2006. Antropologi Sastra: Peranan Unsur-Unsur Kebudayaan dalam Proses Kreatif. Yogyakarta: Pustaka Pelajar.

Shoba, V dan Ngaraj P. 2013. "Eology in Relation to Ecocriticsm: A Theoretical Approach". Indian Journal of Applied Research. (3)1: 85-96.

Sukmawan, Sony. 2016. Ekokritik Sastra: Menanggapi Sasmita Arcadia. Malang: Tim UB Press

Sukmawan, Sony. 2015. Sastra Lingkungan: Sastra Lisan Jawa dalam Perspektif Ekokritik Sastra. Malang: Tim UB Press

Sukmawan, Sony. 2014. Model-model Kajian Ekokritik Sastra. Jurnal Penelitian UB. Agustus 2014. Hlm. 1-17.

Sumardjo, Jakob dan Saini K.M. 1997. Apresiasi Kesusastraan. Jakarta: PT. Garamedia.

Tarigan, Henry Guntur. 1984. Prinsip-prinsip Dasar Sastra. Bandung: PT. Angkasa.

Wiyatmi. 2009. Pengantar Kajian Sastra. Yogyakarta: Pustaka Book Publisher

Wellek. R \& Warren. A. 1990. Teori Kesusastraan. (Diterjemahkan oleh: Melani Budianta). Jakarta: Gramedia 
Volume : 7

Nomor : 3

URL:jurnal.ideaspublishing.co.id Tahun : 2021 